\title{
CRITERIA FOR EVALUATION OF EFFECTIVENESS OF DIFFERENT TYPES OF TREATMENT OF ARTERIAL HYPERTENSION AND INFLUENCE OF DIFFERENT FACTORS ON THE COST OF ANTIGIPERTENSIVE THERAPY
}

Nehoda T.S.

\section{INTRODUCTION}

$30 \%$ of people worldwide blood pressure (BP) exceeding 140/90 $\mathrm{mm} \mathrm{Hg}$. article, that is elevated. In Ukraine the indicator of high blood pressure for the adult population reaches $40 \%$ and in older age groups exceeds $80 \%$. According to modern concepts to $90 \%$ of cases of high blood pressure refers to the primary (essenziale) hypertension ${ }^{1}$. This nosological form is referred to as arterial hypertension ( $\mathrm{AH})$ in English literature and in contemporary publications. Arterial hypertension is the determining factor in the development of severe cardiovascular complications such as cerebrovascular disease, ischemic heart disease, myocardial infarction, congestive heart failure, chronic renal failure, and others ${ }^{2}$. Arterial hypertension also acts as the leading cause of cardiovascular mortality. Registered in the world annually about 3 million deaths due to hypertension and associated diseases and complications. Thanks to an in-depth study of the problem on the basis of large-scale population-based studies have developed a new classification of hypertension, determine the appropriate target levels of blood pressure reduction, as well as produced by the stratification of risk levels and has developed new approaches to pharmacotherapy of this disease ${ }^{3}$. However, despite some achievements associated with the emergence and introduction into the clinic of new modern antihypertensive drugs, the effectiveness of treatment of hypertension is poor. This fact is due to such reasons as complexity and oligosymptomatic the course of $\mathrm{AH}$, unreasonable use outdated and ineffective drugs and treatments, low tendency of patients to

\footnotetext{
${ }^{1}$ Руководства BO3-ISH и были завершены после представления и обсуждения на 7-м совещании BO3-ISH по гипертонии, Фукуока, Япония, 29 сентября 1 октября 1998 г. Предыдущие версии Руководства были опубликованы в Bull WHO 1993, 71: 503-517 и J Hypertens 1993, 11: 905-918. DOI 10,3109 / 10641969909061028.

${ }^{2}$ Карпов Ю.А. Особенности течения и лечения ишемической болезни серца у больных пожилого возраста. Международный медицинский журнал (Москва). Москва, 1999. Т. 2, № 3-4. С. 139-143.

${ }^{3}$ ВООЗ/МОАГ, 1999 : ДАГ-1, 2000; JNC-VII, 2003.
} 
prescribed therapy, as well as dominance on the modern pharmaceutical market (especially domestic) generic drugs, a large number of which are not always defines a rational pharmacotherapy. In addition, in Ukraine reveals the contradiction between the need to adhere to modern standards of therapy, which involves the use of new, typically expensive techniques and drugs, and a constant lack of financing of health care, unwarranted use of the analysis of economic expediency of the use of antihypertensive drugs.

Therefore, in the current conditions, it is quite relevant to study drugs from different clinical and pharmacological groups, taking into account their breadth of prevalence in real clinical practice, as well as their therapeutic efficacy, safety and impact on the well-being of patients.

The results of this analysis should be aimed not only at saving material resources but also at increasing the effectiveness of pharmacotherapy for hypertension.

As a result, it will lead to significant cost savings not only for the individual patient, but for the health care and society at large.

The aim of the study was to develop a new approach to the optimization of pharmacotherapy of arterial hypertension based on a comprehensive clinical and economic evaluation of the use of antihypertensive drugs from different pharmacological groups, taking into account the economic interests of patients.

As a result of the study, the structure of antihypertensive drugs prescribed by doctors for the treatment of arterial hypertension was studied and a comparative retrospective analysis of the therapeutic efficacy of these drugs was conducted; a complete evaluation of the effectiveness of treatment and the impact of various factors on the cost of antihypertensive therapy.

There are different approaches to definition of criteria of efficiency of a particular type of treatment. In this regard, consider several notions of efficiency: efficacy is the degree to which the drugs may exert their main action in "ideal" conditions randomized clinical trials; effectiveness - the extent to which the drugs can carry out their main activity in the conditions of real clinical practice; efficiency - shows how treatment can improve or worsen the economic status of the patient ${ }^{4}$.

On this basis, the criteria of efficiency of treatment, it is necessary to clearly determine which of the following concepts of efficiency will be used. The adequacy of the choice of criterion of the effectiveness of the intervention in most cases determines the degree of validity of the results of

${ }^{4}$ Basskin L.E. Practical Pharvacoeconomics: How to Design, Perform and Analyze Outcomes Research. Advanstar Communications, Cleveland, OH, 1998. 
clinical and economic research ${ }^{5}$ and is mainly determined by the method pharmacoeconomical analysis ${ }^{6}$.

In clinical and economic studies can be used as intermediate criteria of effectiveness (indirect or "surrogate"), and these criteria are expressed in terms of the endpoints (end-point) study ${ }^{7}$.

As intermediate criteria of effectiveness of antihypertensive therapy can be direct (lowering blood pressure, etc.) and indirect clinical effects (reduction in the frequency of complications, reduced readmissions). They are considered indirect ("surrogate") criteria. These include also indicators of changes in the quality of life, health-related or dynamic subjective measure of health - QALY (Quality Adjusted Life Years). Sometimes, especially when alternative methods are compared with the clinical and economic value in the form of performance criteria is used increased safety, reflective safety interventions ${ }^{8}$.

The "true" criteria for the evaluation of the effects of antihypertensive therapy is to change health outcomes (mortality, survival, life expectancy, disability). Among the "true" endpoints emit "hard" (death or recovery) and "soft". The "hard" include mortality from cardiovascular complications, and in "soft" (non-fatal) - stroke, heart attack and other manifestations that do not necessarily lead to death". The use of "hard" and "soft" endpoints ("true" criteria - that is, outlying results) as well as discrete performance indicators (for example, survived, died, or reached the effect), most preferably in conjunction with a greater degree of accuracy of reflection of the results of the intervention.

The effectiveness of the intervention can be expressed in the form of its economic benefits, i.e. profits or economic benefits derived from the use of this treatment.

5 Мальчикова С.В., Тарловская Е.И. Плеотропные эффекты различных вариантов комбинированной терапии артериальной гипертензии. Кардиоваскулярная терапия и профилактика. 2009. № 2. С. 33-38.

6 Kornatskyi V.M. Arterialna hipertoniia - svitova medyko-sotsialna problema porushennia zdorovia naselennia v KhKhI stolitti. Bukev. med. visnyk 2006. № 3. S. 7-10 [in Ukraine].

7 Vukolov E.A. Osnovyi statisticheskogo analiza. Praktikum po statisticheskim metodam i issledovaniyu operatsiy $\mathrm{s}$ ispolzovaniem paketov STATISTICA i EXEL [Uchebnoe posobie. 2-e izd. ispr. i dop.] / E.A. Vukolov. Moscow : FORUM, 2008. 464 s. (Vyisshee obrazovanie) [in Russian].

${ }^{8}$ Воробьев П.А. Сравнительная фармакоэкономическая оценка ... В.В. Ващук, I.B. Стояновський, О.О. Кущ. Львів : Галицька видавнича спілка, 2001.

9 Hansson L. Blood Press 1997 Sep;6(5):299-306 The Hypertension Optimal Treatment (HOT) Study: 24-month data on blood pressure and tolerability. 
The most complete is to evaluate the effectiveness of treatment, taking into account both "real" and indirect criteria. However, in the absence of data on long-term results (because to receive them it is necessary to conduct lengthy and expensive studies) allowed indirect "surrogate" criteria. In addition, the lack of information can make by modelling considering expert opinions.

By definition FDA (Food Drag Administration, USA) under the "surrogate" criteria understand any lab tests or physical findings that are used as the basis for clinical expression of the end point and determined using the patient's state of health, functional activity and survival. Change "surrogate" point under the influence of therapy should reflect changes in the clinical expression of the "true" ultimate standard ${ }^{10}$. Therefore, for an adequate choice of "surrogate" criterion, it is necessary to take into account its direct relevance to the pathophysiology of the disease, the availability of proven impact on the "real" ultimate criterion in quantitative and qualitative terms, as well as accessibility and convenience to study ${ }^{11}$.

In this regard, there are a few "surrogate" criteria, reflecting the severity and duration of the hypotensive effect of antihypertensive drugs, the ability to prevent the development and progression of functional and structural changes in the target organs (protective action), normalize hemodynamics, affect the metabolism, cause adverse or undesirable effects and influence the quality of life of patients.

The most popular among "surrogate" criteria of efficiency of antihypertensive therapy, especially in the domestic literature, are indicators of arterial pressure. This prevalence is probably due to the greatest availability of his research. However, methods of assessment of blood pressure have to use the same technology and be valid. Generally recognized are the following parameters: basal (least stable) blood pressure, the degree of blood pressure control during the day - mean values and variability (standard deviation), the degree of decrease of night is in conjunction with the increase in the daily blood pressure (a predictor of defeat of target organs, frequency of peaks, the intensity decrease of blood pressure to the target level ${ }^{12}$. Used as an indicator of the number of patients achieving the target blood pressure level at a certain dose for a certain period of time. One

${ }^{10}$ Taylor, R. Using health outcomes data to inform decision-making: government agency perspective Text. Pharmacoeconomics. 2001. Vol. 19, № 1. Suppl. 2. P. 33-38.

${ }^{11}$ Reproducibility and validity of quality of life measurements in hypertensive patients on stable medication. Krijnen $\mathrm{P}^{1}$, van Jaarsveld BC, Man in 't Veld AJ, Habbema JD. DOI 10.1016/s0300-2977(97)00006-5

12 Барт Б.Я. Систолическая гипертония у людей пожилого возраста в ... Burt V.L., Cutler J.A., Higgins M. et al. Hypertension. 1995. Vol. 26. P. 60-69. 
measure of the duration of control of blood pressure is TPR (trough-to-peak ratios) - ratio of the final to the greatest effect (peak), expressed as a percentage $^{13}$. The value of this indicator is important because the fluctuations in blood pressure with insufficient duration of control can increase the likelihood of developing cardiovascular complications and the risk of mortality in patients with heart failure. Drugs with high TRP are more likely to retain their antihypertensive effects one day after admission and therefore have a greater ability to prevent cardiovascular complications in the morning, the period when these complications develop most frequently.

All of these indirect performance criteria have a certain clinical significance. However, the use of pharmacoeconomical analysis as a performance indicator only one "surrogate" criterion is not always a sufficient condition ${ }^{14}$. For example, in the study of the antihypertensive properties of the drug and its impact on the final criteria, the choice of reducing the level of average blood pressure as the sole criterion of effectiveness of treatment is not sufficient, since this direct effect does not always lead to reducing the risk of developing cardiovascular complications and premature death (that, for example, found out about the short-range calcium antagonists). With the exception of indicators related to key clinical indicators absolutely proven (e.g. cholesterol and atherosclerosis). So M.S. Roth and R. Davenport (1999) showed that for an adequate assessment of the economic value of antihypertensive treatment should consider not only its direct clinical efficacy, but also to pay special attention to organoprotective properties of the drug. In this regard, these properties are among the most important "surrogate" performance criteria.

Recently extensively studied the impact of antihypertensive drugs on left ventricular hypertrophy $(\mathrm{LVH})$ [16]. Published more than 500 papers devoted to this topic. The most significant of them are considered research Koren M. J. et al. (1990), Yurenev, A.P. (1992), research Muiesan M. et al. (1995), LIFE (Devereux R. B., Dahlof B. et al., 1994) and HOPE (Mathew J. et al., 2001). Their results indicate a significant reduction in mortality in the regression of $\mathrm{LVH}$. And it is important not only the fact of regression, but the degree of its severity. Despite this, there remains a number associated with the problem unresolved fundamental issues. One of them is the problem of the reliability of results instrumental determination of myocardial mass of

13 Леонова М.В. Современный взгляд на конечные точки для оценки антигипертензивной терапии. Качественная клиническая практика. 2002. № 4. C. $18-22$.

${ }^{14}$ Fleming T.R., DeMets D.L. (1996) Surrogate end points in clinical trials: are we being misled? Ann Intern Med 125: 605-613. 
left ventricle (MMLV). According to G.De Simone et al. (1999), dynamics of the indicator MMLV for a particular patient in time cannot be sufficiently informative. Even less informative when compared may be data obtained in different laboratories. To improve the accuracy of the results of echocardiography (Echo KG) use two - and treacherously method. Promising in this respect but extremely expensive may be the method of nuclear magnetic resonance (NMR) imaging.

Another important criterion in the evaluation of antihypertensive therapy are the structural and functional changes of blood vessels. Hypertension leads to their remodeling - adaptive modification of function and then morphology. Distinguish gpatrick, Europe and hypertrophic remodeling of resistance vessels, which is characterized by changing the ratio of the thickness of the vessel wall (mainly the medial layer) to the lumen of the vessel $^{15}$. It can also increase the stiffness (lower elasticity) of the vascular wall due to interstitial fibrosis and accumulation of proteins of the connective tissue matrix. The condition of blood vessels in hypertension, or elasticity, is largely determined by systolic blood pressure (SBP), and peripheral resistance affect the diastolic blood pressure. The issue of primary factors of remodeling and loads of blood pressure is not fully clear, since the blood vessels are the target, and a risk factor for hypertension. However, the indicators of structural and functional vascular changes are considered as markers of the effectiveness of antihypertensive treatment, and predictors of mortality. Indicators of rigidity, extensibility and speed of propagation of the pulse wave reflects the rigidity of the vascular walls and are derived from volume and pressure. The higher rigidity of vessel walls indicates the increase in the risk of left ventricular hypertrophy, and isolated systolic hypertension (a risk factor for coronary heart disease), reduction of elasticity (stretchability) of the development of atherosclerosis. One of the early markers of kidney damage in hypertension is impaired renal function. A decrease in glomerular filtration rate and the appearance of microalbuminuria (MA). Normalization of these indicators during therapy hypertension is regarded as a protective effect of antihypertensive drugs. It is also regarded as one of the "surrogate" performance criteria.

There are a number of evaluation criteria. As a reflection of processes of formation of atherosclerotic plaques in the blood vessels of use ultrasound determination of intima media thickness of carotid arteries in contrast to the traditional invasive angiographic methods.

${ }^{15}$ Heagerty A.M., Aalkjaer C., Bund S.J., Korsgaard N., Mulvany M.J. Small artery structure in hypertension. Dual processes of remodeling and growth. DOI :10.1161/01.hyp.21.4.391 
As a predictor of diabetes, use insulin resistance, which can also be seen as "soft" the ultimate criterion of hypertension. For detection of insulin resistance is the most informative and valid is hyperinsulin isoglycemic glucose load test. One of the main factors in the development of cardiovascular complications - endothelial dysfunction, which can also be seen as an interim measure in the form of sensitivity to endothelin. However, the final recognition of endothelial dysfunction as a surrogate criterion in hypertension remains open due to the conflicting results of various studies.

Despite the fact that the indicators of quality of life related to health, has not found wide application when used in the form of intangible costs, they are one of the main criteria of efficiency of treatment. Medical aspects of quality of life, health-related, can be characterized on the basis of three main interrelated components: functional capacity, perceptions, symptoms and their consequences. The indicators of quality of life, as well as characteristics of the clinical symptoms, change over time depending on the patient's condition that allows the monitoring of the treatment, and if necessary, to conduct its correction. In addition, treatment outcome may be new the symptoms associated with the side effects of drugs. They are able to neutralize the results of treatment or significantly limit its potential outcome, impairing the patient's quality of life.

\section{Socio-demographic factors that influence the cost of antihypertensive therapy}

The participation of the patient in assessing their state of health allows one to obtain valuable and reliable indicators of its General condition. To obtain comparable data and their further use in clinical practice, using standard assessment tools of quality of life, which are the questionnaires index or profile. Most often, subjective evaluation of being, expressed in terms of QALY indices - integral criterion, reflecting the actually or hypothetically saved life years of the patient taking into account the influence of the factors treatment and disease progression. QALY allows you to integrate mortality and morbidity to assess the health status of terms of years lived qualitatively ${ }^{16}$. In fact, QALY is the product of the number of years of life on the subjective dynamic indicator of its quality already implemented, in case the lookup of this index from survey results that reflect the functional state or the severity of the condition, or expected, given the preferences of the patient or the doctor. The subjective value of the dynamic indicator of well-being, whatever method it was not designed, is in the range

${ }^{16}$ Новик А.А., Ионова Т.И. influencing women's and men's health-related quality of life after five months. Psychology, Health \& Medicine. 2002. 
from 0.0 to 1.0, reflecting respectively the worst and best state of being. All changes in health status lie in this interval. Due to changes in the quality of life (or rather, feel) in time, the overall QALY represents the sum of QALY values calculated for each year of life, given its quality.

In addition to the above objective and subjective criteria, according to the literature, there are alternative criteria for comparison of effectiveness. So according to many studies V.A. Skutelis and singing. (2000) found significant differences of the initial data of efficacy of drugs that allowed to identify characteristic efficiency (Dmin-Dmax), and not a point integral characteristics. Given the tactics of treatment, these authors carried out the assessment of these indicators in the use of diuretics. Consideration was given to such factors as onset of effect, the severity of the maximum effect, duration of action, side effects, etc. it has Been shown that among the diuretics given performance indicators (Dmin-Dmax), was the leader klopamida and indapamide. There was also a generalized indicator of the efficiency of the medicines associated with the use of scaling for each of the clinical manifestations of drug action.

There are a number of factors that can have a significant impact on the effectiveness of treatment of hypertension and its cost.

It is shown that use as a method of measuring blood pressure daily blood pressure monitoring leads to a significant cost reduction. This method allows you to more objectively measure blood pressure, and to reduce costs through the optimal selection of antihypertensive therapy and exclusion of hypertension "white coat" hypertension ${ }^{17}$, whose prevalence in the population reaches $21 \%$. This results in savings of approximately $\$ 110000^{18}$.

Of patients factors affecting the value of antihypertensive therapy, are gender, age, stage and severity of disease, presence of comorbidity, and the degree of adherence to treatment.

As one of the most important factors is the initial level of blood pressure. From the clinical point of view, the threshold of intervention is a rise in blood pressure above $140 / 90 \mathrm{~mm} \mathrm{Hg}$. and its normalization is absolutely justified, while with pharmaco-economic position in this respect, there are some contradictions. According to B.G. Jonsson (1996), the cost per year of life saved in the treatment of hypertension at least in initial higher blood pressure. In men aged 45-69 years with initial diastolic pressure (DT) 90-94 mm Hg.

17 Aitken L., Addison C. The cost-effectiveness of ambulatory blood pressure monitoring. Prof Nurse. 1996 Dec; 12(3) : 198-202.

${ }^{18}$ Фармакоэкономические аспекты применения $\beta$-блокаторов при артериальной гипертонии и сердечной недостаточности. / О.Д. Остроумова [та ін.]. Кардиология. 2003. T. 43, № 5. C. 87-96. 
the cost per year of life saved was about $\$ 9315$, whereas men in the same age group from the source DT 100-104 mm Hg. it was only \$137. Similar results were obtained in women with hypertension. It is also established that antihypertensive therapy leads to savings in the treatment of men and women older than 45 years with the initial level of DT $105 \mathrm{~mm} \mathrm{Hg}$. and more, as well as women older than 70 years when the original DT 100-104 mm Hg.

Another important factor affecting the value of antihypertensive therapy is the age of the patients. As you know, with age increases the risk of cardiovascular complications, prevention with blood pressure reduction will lead to significant savings in almost all cost elements. Noted a more pronounced economic efficiency of treatment of hypertension in patients of middle and elderly age. It is shown that the cost per year of life saved at an output of diastolic pressure $95-99 \mathrm{~mm} \mathrm{Hg}$.St. in men with hypertension younger than 45 years was $\$ 106849$, at the age of $45-69$ years - $\$ 4658$, and older than 69 years - a total of $\$ 1918$. At the age of 35 years the cost of extending the life of the patient with hypertension is higher for men and 45 years for women. For young men and women, the cost of additional years of life with age significantly increases and reaches its maximum for 55 years. Then is observed a progressive reduction in the cost of antihypertensive therapy. In this regard, it was concluded on the unprofitability of antihypertensive therapy in young patients with mild hypertension in connection with the revealed a moderate decrease in quality of life during treatment and the relatively low incidence of vital complications in patients of this age group. However, the lack of profitability of pharmacotherapy of hypertension in young patients and in patients with relatively low baseline levels of blood pressure, is not a reason for refusal of treatment. Although drug therapy in these cases and implies an increase of direct medical costs, a simple comparison of the total costs of treatment of the disease and its complications has convincingly proved the necessity of redistribution of financial resources in the direction of increase of efficiency of preventive.

The literature data about the influence of gender in patients with hypertension on the economic efficiency of treatment of hypertension is controversial. Some authors reported that the cost of antihypertensive therapy in the age of 70 years for men lower than in women ${ }^{19}$, however from other sources it follows that there are no significant differences in the profitability of antihypertensive therapy in men and women.

The factors that largely determine the cost of antihypertensive therapy include the degree of patient compliance with medical regulations -

${ }^{19}$ Bulpitt C.J., Fletcher A.E. Cost-effectiveness of the treatment of hypertension. Clin. Exp. Hypertens. 1993. 
compliance. Low patient compliance is $31 \%$ among the reasons for inadequate blood pressure control in the population.

The factors that promotes adherence to treatment, identify the source of high blood pressure, female gender, high educational level, higher income level, marriage status, high level of culture, the use of fixed combination drugs. Among the factors that reduce commitment, have the value of a complex dosing regimen of the drugs, their side effects, high cost, too rapid a decrease in blood pressure, Smoking, young age, long-term treatment, alcohol abuse, low level of culture. In addition, patients often there is a contradiction between the desire for quality treatment and a quite understandable reluctance to increase spending on its implementation.

Patients with the same diastolic blood pressure as very high and low level complaintant negatively affects the economic side of treatment, while the average level of commitment is the most expedient from a pharmacoeconomic point of view. At high complants grow the cost of purchasing expensive medications and more frequent visits to the doctor. Low degree of commitment to the prescribed treatment, carelessness in implementing the physician's prescription, and the more self-discontinuation of medications can lead to negative consequences - cardiovascular complications that require aggressive treatment or even hospitalization, which leads to a substantial increase in the cost of the treatment of hypertension. So in the United States during the year, the break in treatment do $86 \%$ of patients, the average cost of treatment increases by $\$ 873$, and $\$ 637$ expended in connection with hospitalization $^{20}$. For many patients, even if they are aware of the effectiveness of blood pressure reduction in terms of long-term outcomes, this is not a sufficiently convincing argument for permanent medication. The degree complaintant can cause the development side effects of antihypertensive therapy, which can lead to a significant increase in the cost of treatment in connection with the necessity of their medical treatment.

In almost all manuals for the treatment of hypertension, patients with hypertension are recommended to adhere to the hyposal diet and a rational motor regime, that is, to carry out lifestyle modification. Of course, these measures have a positive effect on the level of blood pressure and, as a consequence, on the overall health. However, not all patients are ready for a change in their lifestyle due to both objective and subjective reasons. This, in turn, reduces compliance, and therefore the overall effectiveness of treatment and its cost.

${ }^{20}$ McCombs J.S., Nichol M.B., Newman C.M., Sclar D.A. The costs of interrupting antihypertensive drug therapy in a Medicaid population. DOI $: 10.1097 / 00005650$ 199403000-00003 
Frequency of taking the drug is also a very important factor affecting adherence. It is established that at two doses (morning-evening) adherence to treatment decreases by 5 times in comparison with a single dose. In addition, during the selection of antihypertensive therapy in a particular patient costs may be more significant than at the stage of routine therapy.

The initial choice of a group of drugs for the treatment of hypertension has a significant impact on the frequency of subsequent replacement of one antihypertensive drug with another or the termination of treatment. These factors can lead to a significant increase in spending.

\section{The leading aspects that determine the success of hypertension therapy}

Therefore, one of the leading aspects that determine the success of hypertension therapy is the choice of the optimal drug (or combination) for antihypertensive therapy. This problem is quite complicated. First of all, it is related to the features of hypertension, such as low-symptomatic course and its multifactorial. To date, no reliable predictors have been identified to indicate the dominant mechanism for the development of hypertension in a particular patient, and therefore to make the right choice of optimal therapy. At the same time, the adherence to treatment is influenced by the group of antihypertensive drugs, which was used as the therapy of the first choice. It is shown that, depending on the first prescription drug, $83 \%$ of patients receiving angiotensin-converting enzyme inhibitors, $81 \%$ of patients receiving calcium antagonists, $78 \%$ of patients receiving beta-blockers, $74 \%$ of patients receiving diuretics continue to be recommended for a year. The same situation persists in 4.5 years $-53 \%, 47 \%, 49 \%$ and $40 \%$, respectively. Thus, antihypertensive therapy initiated with ACEF drugs provided the best adherence to the treatment regimen. However, in terms of cost, the use of angiotensin-converting enzyme inhibitors is one of the most expensive alternatives for the treatment of hypertension. According to B.G. Jonsson and M. Johannesson (1999), in the study of the annual cost of antihypertensive monotherapy using different clinical and pharmacological groups, diuretic therapy was estimated to be the least costly, more than twice the cost of prescribing calcium and beta antagonists. blockers, and more than four times when using angiotensin-converting enzyme inhibitors. At the same time stands out another trend: the larger.

Similar data were obtained in other studies. According to J.T. Edelson et al. (1990) the cost of one year of life saved by treatment with various antihypertensive drugs (patients 35-64 years without coronary heart disease) was $\$ 10,900$ for propranolol, $\$ 16,400$ for hydrochlorothiazide, nifedipine, prazosin and captopril - $\$ 31,600, \$ 61,900$ and $\$ 72,900$, respectively. 
In another comparative pharmacoeconomic study conducted by S.D. Ramsey et al. (1999) studied the pharmacotherapy of hypertension with drugs of the main groups: enalapril, amlodipine, acebutolol and chlorthalidone. Costs in this study included the cost of the drug, monitoring, correction of side effects and complications, as well as the cost of changing therapy when needed. In the last three study groups, most of the total costs accounted for the costs associated with the acquisition of medicines. It was shown that patients treated with amlodipine monotherapy were more likely to reach their target blood pressure level. The highest percentage of patients with target BP achieved was in the same group. However, the lowest cost was observed with the use of chlorthalidone (\$641). In other groups, the costs were higher and amounted to $\$ 948, \$ 946$ and $\$ 920$, respectively, when using enalapril, amlodipine and acebutolol.

From the above data it becomes clear that the cost of antihypertensive therapy is higher when using angiotensin-converting enzyme inhibitors and calcium antagonists and less when using beta-blockers and diuretics.

The low cost compared to other classes of antihypertensive drugs is a clear advantage of thiazide diuretics. It has been shown that in the UK, the average cost of therapy with bendrofluazide is 0,004 pounds per day, while the cost of one-day therapy with amlodipine, atenolol, verapamil, diltiazem, captopril, lisinopril, metoprolol, nifedipine, ramipril, enalapril ranges from 0.12 to 0.46 pounds. In the US, the cost of a monthly course of treatment for hypertension with thiazide diuretics is only $\$ 1-3$. This is much lower than the cost of a month's worth of beta blockers (\$5-24), calcium antagonists (\$18-56), and angiotensin-converting enzyme inhibitors (\$19-46). According to A.K. Pearce et al. (1998), the cost of a five-year course of diuretics ( $25 \mathrm{mg}$ hydrochlorothiazide per day) is $\$ 55$. Much higher the cost of antihypertensive therapy when using other antihypertensive drugs. For example, the cost of a five-year treatment with beta blockers ranges from $\$ 637$ to $\$ 1212$, calcium antagonists range from $\$ 1495$ to $\$ 4026$, angiotensin-converting enzyme inhibitors range from $\$ 1095$ to $\$ 1820$, alpha blockers range from $\$ 1758$ to $\$ 2260$.

Analysis of the cost of antihypertensive therapy in Ukraine has also shown that diuretics and beta-blockers have the lowest cost, followed by calcium antagonists and angiotensin-converting enzyme inhibitors. The most expensive drugs were alpha-blockers and AT II receptor antagonists. Moreover, the price of an equivalent daily dose of alpha-blocker of cardura (doxazosin) was almost 43 times, and the antagonist of the receptor of the AT II cosaire 71 times higher than the beta-blocker of propranolol.

However, in general, the cost of antihypertensive therapy in Ukraine is lower than the cost of similar treatment abroad. This is due to a number of 
reasons, including the fact that in Ukraine antihypertensive drugs are mainly represented by generics. In addition, most large pharmaceutical companies, when selling some of their drugs in Ukraine, are dumping and making significant discounts of up to $30 \%$.

The cost of antihypertensive drugs and their therapeutic efficacy within a single group may vary significantly. According to K.A. Johnson et al. (1995), who conducted a comparative analysis of the cost of treatment with different ACEIs on the example of 977 patients with hypertension in the United States, showed that the price of achieving the target pressure using fosinopril (15.9 mg / day) does not exceed the cost of using quinapril (19.9 mg / day) or ramipril (5.4 mg / day) and significantly less cost when using enalapril (10.2 mg / day).

Cost and effectiveness may also differ in antihypertensive agents, which are based on the same substance, ie drugs with the same international nonproprietary name (INN). An analysis of the use of indapamide generics was conducted, which showed the superiority of the original preparation of ariphon over its reproduced counterpart with the trade name indapamide, from a clinical and, in some aspects, from an economic point of view.

One of the decisive factors that affect both the effectiveness of the treatment and, to a great extent, its cost, is the process of acquiring the drug from a pharmacy network. Often, the patient is offered to buy the "same" drug but with a different commercial name and, therefore, with a different cost. In such situations, it is usually a matter of generics, which can differ not only in value but also in the degree of therapeutic efficacy. In the absence of reliable information about the possible replacement of expensive original drugs with high-quality generics, the cost factor is often decisive in the choice of therapy. In this regard, in the real clinical practice, there are different principles for choosing a specific drug for the treatment of patients. Many doctors are inclined to use more expensive original drugs, often without real clinical advantages over cheaper generics. The other part of the doctors, taking care of the material well-being of the patient, prefers to prescribe more affordable drugs that sometimes do not meet the GCP and GMP standards. Therefore, not always the low cost of generics, attractive when purchased, saves on the overall cost of treatment.

As evidenced by actual clinical practice, drugs with different commercial names, which have the same active ingredient, may differ significantly in their therapeutic efficacy. Obviously, the cheapness of some generics is not always a factor that reduces the cost of treatment, which is most often due to the low therapeutic efficacy of the reproduced drugs and the higher incidence of side effects. 
In addition, more than $25 \%$ of urban residents of our country are treated independently. According to statistics, $37 \%$ of Ukrainians with hypertension never visited a doctor during the year. The sales of over-the-counter drugs are $45 \%$ of the total sales of pharmaceuticals.

\section{CONCLUSIONS}

The conducted analysis reveals several basic patterns. First of all, it is the widespread prevalence of hypertension in the population. Acting as the most significant risk factor for cardiovascular disease, arterial hypertension determines the structure and extent of morbidity and mortality from cardiovascular disease that lead to significant material costs. A number of large studies have proven the need to control blood pressure, which reduced to a target level positively affected distant endpoints. Antihypertensive therapy, which contributes to the significant cost savings associated with preventing cardiovascular complications, is nevertheless quite costly. Of the modern antihypertensive agents, the most affordable are the groups of "old" drugs - diuretics and beta-blockers, much more expensive than the "new" groups of drugs - calcium antagonists and angiotensin-converting enzyme inhibitors, and the most expensive are blockers of AT II receptors and alphablockers. In many studies (STOP, HANE, TOMHS, NORDIL, etc.), no significant differences were found between "new" and "old" drug groups, both in the severity of the antihypertensive effect and in the possibility of preventing complications. Therefore, most recommendations for the treatment of hypertension diuretics and beta blockers are recognized as "first line" in the treatment of hypertension. However, around the world, there is a trend of displacement of these drugs by calcium antagonists and ACE inhibitors. Data on the use of different groups of antihypertensive drugs in the population and the degree of their effectiveness in the real world are quite controversial and heterogeneous, so, of course, need some clarification.

Despite the variety of antihypertensive drugs, a significant problem is the lack of control of hypertension in the population. The reasons are different. One is to determine the primary choice of an antihypertensive drug. The profitability of the treatment of hypertension is ultimately determined not by the class of antihypertensive drugs used, but by a specific drug, since the price of drugs varies significantly within each group.

In addition to the large number of original drugs in Ukraine there is a huge number of reproduced analogues that have a lower price.

Therefore, for a scientifically sound, rather than intuitive or empirical evaluation, a comprehensive clinical and economic analysis is needed, which, based on the results of pharmacoepidemiological and clinical research on antihypertensive drugs, would help to optimize pharmacotherapy of hypertension. 


\section{SUMMARY}

In Ukraine, the prevalence of high blood pressure for adults reaches $40 \%$, and in the older age groups exceeds $80 \%$. Arterial hypertension is a determining factor in the development of severe cardiovascular complications, such as circulatory disorders, coronary heart disease, myocardial infarction, chronic heart failure, chronic renal failure, and others. Despite some advances in the emergence and introduction of new modern antihypertensive drugs into the clinic, the effectiveness of treatment for hypertension leaves much to be desired. In Ukraine, there is a contradiction between the need to adhere to the current level of therapy, which involves the use of new, as a rule, expensive techniques and drugs, and the constant lack of funding for health care. Therefore, in the current conditions it is quite relevant to study drugs from different clinical and pharmacological groups, taking into account their breadth of prevalence in real clinical practice, as well as their therapeutic efficacy, safety and impact on the well-being of patients.

The study investigated the structure of antihypertensive drugs prescribed by physicians for the treatment of hypertension and conducted a comparative retrospective analysis of the therapeutic efficacy of these drugs; a complete evaluation of the effectiveness of treatment and the impact of various factors on the cost of antihypertensive therapy.

\section{REFERENCES}

1. Руководства BO3-ISH и были завершены после представления и обсуждения на 7-м совещании BO3-ISH по гипертонии, Фукуока, Япония, 29 сентября - 1 октября 1998 г. Предыдущие версии Руководства были опубликованы в Bull WHO 1993, 71: 503-517 и J Hypertens 1993, 11: 905-918. DOI: 10,3109 / 10641969909061028.

2. Карпов Ю.А. Особенности течения и лечения ишемической болезни серца у больных пожилого возраста. Международный медииинский журнал (Москва). Москва, 1999. Т. 2. № 3-4. С. 139-143.

3. ВОО3/МОАГ, 1999: ДАГ-1, 2000; JNC-VII, 2003

4. Basskin L.E. Practical Pharvacoeconomics: How to Design, Perform and Analyze Outcomes Research. Advanstar Communications, Cleveland, $\mathrm{OH}, 1998$

5. Мальчикова С.В., Тарловская Е.И. Плеотропные эффекты различных вариантов комбинированной терапии артериальной гипертензии. Кардиоваскулярная терапия и профилактика. 2009. № 2. C. 33-38. 
6. Kornatskyi V.M. Arterialna hipertoniia - svitova medyko-sotsialna problema porushennia zdorovia naselennia $\mathrm{v}$ KhKhI stolitti. Bukev. med. visnyk 2006. № 3. S. 7-10 [in Ukraine].

7. Vukolov E.A. Osnovyi statisticheskogo analiza. Praktikum po statisticheskim metodam $\mathrm{i}$ issledovaniyu operatsiy s ispolzovaniem paketov STATISTICA i EXEL [Uchebnoe posobie. - 2-e izd. ispr. i dop.]. Moscow : FORUM, 2008. 464 s. (Vyisshee obrazovanie) [in Russian].

8. Воробьев П.А. Сравнительная фармакоэкономическая оценка ... В.В. Ващук, І.В. Стояновський, О.О. Кущ. Львів : Галицька видавнича спілка, 2001.

9. Hansson L. Blood Press 1997 Sep;6(5):299-306 The Hypertension Optimal Treatment (HOT) Study: 24-month data on blood pressure and tolerability.

10. Taylor R. Using health outcomes data to inform decision-making: government agency perspective Text. Pharmacoeconomics. 2001. Vol. 19, № 1. Suppl. 2. P. 33-38.

11. Reproducibility and validity of quality of life measurements in hypertensive patients on stable medication. Krijnen $\mathrm{P}^{1}$, van Jaarsveld $\mathrm{BC}$, Man in 't Veld AJ, Habbema JD. DOI: 10.1016/s0300-2977(97)00006-5

12. Барт Б.Я. Систолическая гипертония у людей пожилого возраста Burt VL., Cutler JA., Higgins M. et al. Hypertension. 1995. Vol. 26. P. 60-69.

13. Леонова М.В. Современный взгляд на конечные точки для оценки антигипертензивной терапии. Качественная клиническая практика. 2002. № 4. С. 18-22.

14. Fleming TR, DeMets DL (1996) Surrogate end points in clinical trials: are we being misled?Ann InternMed 125: 605-613

15. Heagerty A.M., Aalkjaer C., Bund S.J., Korsgaard N, Mulvany M.J. Small artery structure in hypertension. Dual processes of remodeling and growth. DOI:10.1161/01.hyp.21.4.391

16. Новик А.А., Ионова Т.И. influencing women's and men's healthrelated quality of life after five months. Psychology, Health \& Medicine. 2002.

17. Aitken L., Addison C. The cost-effectiveness of ambulatory blood pressure monitoring. Prof Nurse. 1996 Dec;12(3): 198-202.

18. Фармакоэкономические аспекты применения $\beta$-блокаторов при артериальной гипертонии и сердечной недостаточности. / О.Д. Остроумова [та ін.]. Кардиология. 2003. Т. 43. № 5. С. 87-96.

19. Bulpitt C.J., Fletcher A.E. Cost-effectiveness of the treatment of hypertension. Clin. Exp. Hypertens. 1993. 
20. McCombs J.S., Nichol M.B., Newman C.M., Sclar D.A. The costs of interrupting antihypertensive drug therapy in a Medicaid population. DOI:10.1097/00005650-199403000-00003.

\section{Information about author:}

Nehoda T. S.,

Associate Professor of the Department of Pharmacy and Industrial Technology of Drugs

Bogomolets National Medical University

13, Taras Shevchenko Boulevard, Kyiv, 01601, Ukraine 